\title{
Find out how Much it Means to Me! The Importance of Interpersonal Respect in Work Values Compared to Perceived Organizational Practices
}

\author{
Niels van Quaquebeke, Sebastian Zenker, and Tilman Eckloff
}

Accepted for publication in Journal of Business Ethics

\begin{tabular}{|l|l|}
\hline \multicolumn{2}{|l|}{ ERIM REPORT SERIES RESEARCH IN MANAGEMENT } \\
\hline ERIM Report Series reference number & ERS-2008-085-ORG \\
\hline Publication & December 2008 \\
\hline Number of pages & 23 \\
\hline Persistent paper URL & http://hdl.handle.net/1765/14311 \\
\hline Email address corresponding author & nquaquebeke@rsm.nl \\
\hline Address & Erasmus Research Institute of Management (ERIM) \\
& RSM Erasmus University / Erasmus School of Economics \\
& Erasmus Universiteit Rotterdam \\
& P.O.Box 1738 \\
& 3000 DR Rotterdam, The Netherlands \\
& Phone: + 31 10 408 1182 \\
& Fax: + 31104089640 \\
& Email: info@erim.eur.nl \\
& Internet: $\quad$ www.erim.eur.nl \\
\hline
\end{tabular}

Bibliographic data and classifications of all the ERIM reports are also available on the ERIM website: www.erim.eur.nl 


\section{ERASMUS RESEARCH INSTITUTE OF MANAGEMENT}

\section{REPORT SERIES}

\section{RESEARCH IN MANAGEMENT}

\begin{tabular}{|c|c|}
\hline \multicolumn{2}{|c|}{ ABSTRACT AND KEYWORDS } \\
\hline Abstract & $\begin{array}{l}\text { Two large online surveys were conducted among employees in Germany to explore the } \\
\text { importance employees and organizations place on aspects of interpersonal respect in relation to } \\
\text { other work values. The first study }(\mathrm{N}=589 \text { ) extracted a general ranking of work values, showing } \\
\text { that employees rate issues of respect involving supervisors particularly high. The second study } \\
(\mathrm{N}=318) \text { replicated the previous value ranking. Additionally, it is shown that the value priorities } \\
\text { indicated by employees do not always match their perceptions of actual organizational practices. } \\
\text { Particularly interpersonal respect issues that involve employees' supervisors diverge strongly } \\
\text { negative. Consequences and potentials for change in organizations are discussed. }\end{array}$ \\
\hline Free Keywords & work values, interpersonal respect, organizational culture, organizational practices \\
\hline Availability & $\begin{array}{l}\text { The ERIM Report Series is distributed through the following platforms: } \\
\text { Academic Repository at Erasmus University (DEAR), DEAR ERIM Series Portal } \\
\text { Social Science Research Network (SSRN), SSRN ERIM Series Webpage } \\
\text { Research Papers in Economics (REPEC), REPEC ERIM Series Webpage }\end{array}$ \\
\hline Classifications & $\begin{array}{l}\text { The electronic versions of the papers in the ERIM report Series contain bibliographic metadata } \\
\text { by the following classification systems: } \\
\text { Library of Congress Classification, (LCC) LCC Webpage } \\
\text { Journal of Economic Literature, (JEL), JEL Webpage } \\
\text { ACM Computing Classification System CCS Webpage } \\
\text { Inspec Classification scheme (ICS), ICS Webpage }\end{array}$ \\
\hline
\end{tabular}


Running head: Perceived Importance of Interpersonal Respect

Find out how Much it Means to Me! The Importance of Interpersonal Respect in Work Values Compared to Perceived Organizational Practices

Niels van Quaquebeke

Rotterdam School of Management, Erasmus University

Sebastian Zenker

RespectResearchGroup, University of Hamburg

Tilman Eckloff

RespectResearchGroup, University of Hamburg

(Accepted for publication in Journal of Business Ethics)

Keywords: Work Values, Interpersonal Respect, Organizational Culture, Organizational Practices 


\begin{abstract}
Two large online surveys were conducted among employees in Germany to explore the importance employees and organizations place on aspects of interpersonal respect in relation to other work values. The first study $(N=589)$ extracted a general ranking of work values, showing that employees rate issues of respect involving supervisors particularly high. The second study $(N=318)$ replicated the previous value ranking. Additionally, it is shown that the value priorities indicated by employees do not always match their perceptions of actual organizational practices. Particularly interpersonal respect issues that involve employees' supervisors diverge strongly negative. Consequences and potentials for change in organizations are discussed.
\end{abstract}


Find out how Much it Means to Me! The Importance of Interpersonal Respect in Work Values Compared to Perceived Organizational Practices

While leadership studies in the fifties have already emphasized that respectful leader behaviour towards employees is an essential antecedent of employee satisfaction and performance (i.e. the "considerate leadership style" as described in Judge, Piccolo, \& Ilies, 2004; Kerr, Schreisheim, Murphy, \& Stogdill, 1974; Stogdill, 1950), recent research undertakings, initially stemming from social justice research, further highlight that interpersonal respect among members of a group can evoke group beneficial behavior, such as extra effort or extra role behaviour (De Cremer, 2003; Miller, 2001; Simon \& Stürmer, 2003; Sleebos, Ellemers, \& de Gilder, 2006; Tyler \& Blader, 2000). In other words, interpersonal respect, be it between leaders and their subordinates or among colleagues, affects outcome variables which are generally regarded as beneficial for an organization and its performance.

With the present paper we want to complement previous findings and explore the importance of interpersonal respect to employees themselves. Naturally, most people would agree that respect is very important to them. Yet, how do employees' concerns for interpersonal respect differ with regard to their supervisors and colleagues? And, how would employees rank the importance of respect at the workplace in comparison to other more classic work values, such as income, health, or work-life balance? - all of these being issues which human resources departments need to consider when prioritizing the different aspects in an organizational development scheme.

By focusing on employees' relative interest in respect, we hope to underline that human resources strategies, which aim to tackle issues of respect in organizations, might receive 
considerable backing by employees which would in return facilitate organizational change in that domain.

\section{Background}

Values are generally seen as intrinsic and enduring perspectives individuals hold throughout different stages in their lifetime (Bem, 1970; Jones \& Gerard, 1967; Rokeach, 1973). They indicate "what a person consciously or subconsciously desires, wants, or seeks to attain" (Locke, 1976, p. 1304). Work values represent these sentiments in applied settings, signaling what people strongly care about in the work place. Hence, work values are commonly assessed as people's preferences for certain objects or outcomes, such as job security, level of salary, etc.. Following this approach (for a further discussion of different conceptions see Meglino \& Ravlin, 1998), work values are somewhat similar to the valence term in expectancy models of motivation (cf. Vroom, 1964). They have a substantial impact on the actual behavior displayed in the workplace, for example, by encouraging individuals to act in certain ways (Epstein, 1979; Rokeach, 1973; Williams, 1979), or affecting job choice decisions (Judge \& Bretz, 1992). With the present study we seek to integrate "interpersonal respect" in the relational preference space of classic work values. For this purpose, respect needs to be differentiated along two lines which have been pointed out by previous theoretical (Darwall, 1977; Dillon, 2003; van Quaquebeke, Henrich, \& Eckloff, 2007) and empirical works (Simon \& Stürmer, 2005; Tyler \& Blader, 2000, 2003). The first kind entails the general acknowledgement of the equivalence of another person, referred to as "recognition respect" or respect for persons. The second kind is an acknowledgement of expertise or skill, referred to as "appraisal respect" or respect for work. These two kinds, although both named respect, are very different in their essence. 
Recognition respect is very similar to the kind of respect the philosopher Kant (2003) proposed. It follows a categorical imperative to respect other human beings by not only seeing them as means to an end, but also as an end in themselves (see Hill, 1998), i.e., as a factor to include in one's equation of self-regulation (Simon, 2007). In an organization this respect may be portrayed by supervisors who do not only focus on performance aspects of their subordinates, but also on their human side, e.g., when supervisors are compassionate and understanding in a time of a private crisis on behalf of the subordinate (Bass \& Stogdill, 1990). This kind of respect is somewhat similar to the "golden rule" which states that all people deserve to be treated how one would want to be treated oneself. There is no question if this kind of respect is deserved or not. It is not about a personal appreciation or favoring, but about following a clear set of conventions, which give people equal rights - even though they are individuals and as such different. Research underlined this reasoning by confirming formal rules in justice issues as an antecedent of recognition respect (Tyler \& Blader, 2000).

Appraisal respect, on the other hand, points at an entirely different phenomenon. It is about the esteem one receives if one performs, masters a skill, or accomplishes things that set one positively apart from the rest (Darwall, 1977; Dillon, 2003; van Quaquebeke et al., 2007). Whereas recognition respect involves a message of equality, appraisal respect thus entails the opposite: It acknowledges positive differences and rewards them with status. This kind of respect does not draw itself from a general normative law; instead, it derives its legitimacy from the perceived object itself. It or its actions demand respect. Thus, in an organizational setting, appraisal respect might become evident in a supervisor who acknowledges work or performance, may it be through spoken recognition, a promotion, or a raise in salary. Similarly, when employees state that they work for a supervisor they deeply respect, this is likely an indication of 
appraisal respect. In contrast to recognition respect, which seems to be a result of formal rule following, appraisal respect seems to rely more on the informal treatment in justice concerns (Tyler \& Blader, 2000). It is about acknowledging differences apart from the formal system.

Although the antecedents and core messages of recognition and appraisal respect are quite different, the consequences of both on individuals who receive either are relatively similar. Both kinds of respect have shown to heighten individuals' self-esteem when received (Smith, Tyler, Huo, Ortiz, \& Lind, 1998; Tyler \& Blader, 2000). Moreover, people who were respected seem to lose concern for their personal image and rather engage in efforts to improve their group's image if it is under threat (Branscombe, Spears, Ellemers, \& Doosje, 2002, however, the reverse causality may also exist). Both, recognition or appraisal respect, have shown to evoke a heightened degree of group serving behavior either in individuals' in-role or extra-role organizational behavior (Simon \& Stürmer, 2003, 2005; Tyler \& Blader, 2000). This commitment towards one's group even occurs if individuals receive a simultaneous message of disliking (Spears, Ellemers, \& Doosje, 2005), a message of group exclusion (Simon \& Stürmer, 2005), or negative performance evaluations (Simon \& Stürmer, 2003). Other studies, stemming from leadership research, additionally demonstrate that a considerate leadership style - i.e., leader behavior which shows concern and respect for subordinates by looking out for their welfare and expressing appreciation and support (Bass \& Stogdill, 1990; Eckloff \& van Quaquebeke, 2008) - enhances subordinates' job satisfaction, their motivation, and their performance (Judge et al., 2004). Both kinds of respect, as different as they are, seem to work as a social lubricant and can thus in their consequences be regarded as highly pivotal in the organizational interplay. 
For the present paper, we will further distinguish between these two kinds of respect along the two predominant relationships employees are involved in. We examine the appraisal respect employees may receive for their work (1) from their supervisors, and (2) from their colleagues; and the recognition respect they receive as persons (3) from their supervisors, and (4) from their colleagues. Additionally, we suspect that working for or with someone, one can respect, may also be desirable to people, which led us to include two more facets: the appraisal respect that subordinates themselves feel towards (5) their supervisors, and (6) towards their colleagues. ${ }^{1}$

While previous empirical studies mainly focused on the interplay between respect and outcome variables, we are solely interested in how desirable these aspects of interpersonal respect are to employees themselves. If our study can show that the different facets of respect are highly desired by employees, previous findings would be triangulated, giving more arguments in support of human resources strategies which attempt to tackle these issues in organizational development processes (above a means for organizational effectiveness as outlined by previous research).

\section{Method}

\section{Procedure}

We collected two samples via online surveys. We cautiously conducted the surveys according to recommendations given in the field (Birnbaum, 2004; Kraut et al., 2004). For one, the surveys were server-side programmed so that anyone would be able to enter them regardless of their browser's security settings. Moreover, we assigned each participant a cookie session id which made it almost impossible for inexperienced users to participate in the same survey from the same computer again. 
To increase response rate, lower the drop-out rate, and prevent strong self selection biases, we included motivators for both samples, such as feedback of the results and a lottery for gift vouchers. Furthermore, we included a progress bar showing participants at all times how far they have come in the survey. We also assured participants at the beginning that the research would be conducted anonymously. At the end of the questionnaire people were able to decide if they wanted to have their data analyzed for scientific purposes or if they would prefer to be deleted form the data pool. In any case, we provided people who were interested in the results with an opportunity to sign up in a different database so that names and emails could not be linked to any data entries in the survey. Finally, we pretested the survey on different browsers and different screen resolutions to assure that the survey would look and behave the same way on all systems. With all measures taken to prevent common shortcomings of online research, we are confident that our data are of a quality that lets us have faith in the results - at least to the extent that we would have it for classic paper and pencil studies, too.

\section{Samples}

\section{Study 1}

When recruiting participants for the first sample, we followed a multi-site-multi-entry strategy to prevent strong sampling biases. We recruited participants from diverse backgrounds via various German public media websites. The entry was either a banner, a teaser box, or a short article on the objective of the survey. Altogether, 589 participants completed the survey and met the requirements introduced in the above procedure. The sample's mean for age was 38 years $(S D=11.2)$. Women made up $45 \%$ of the sample. The total employment time in life spread around 15 years $(S D=12.6)$. The various educational degrees were well-balanced. Academically educated employees made up around $55 \%$ of the sample. $56 \%$ of all participants had completed a 
vocational training. 58\% indicated that they had previously had a position in which they supervised other employees. $36 \%$ of the sample had children.

Study 2

We recruited participants for the second sample half a year later via direct mailings in various companies and organizations from different branches in Germany. Here, 318 participants completed the survey and met the requirements introduced in the above procedure. The sample's mean for age was 37 years $(S D=10.9)$. Women made up 55\% of the sample. The total employment time in life spread around 14 years $(S D=11.3)$. Academically educated employees were represented quite strongly in this sample, making up roughly $71 \%$ of the sample. $42 \%$ of all participants had completed a vocational training. $42 \%$ indicated that they currently have a position in which they supervise other employees. $34 \%$ of the sample had children.

\section{Measures}

The list of work values encompassed classical aspects of work values typically investigated in companies (such as the original IBM survey later used by Hofstede, 1991; or typical values assessed by consultancies, e.g., Mason, 1994): (1) having high job security, (2) receiving a high income, (3) having good career opportunities, (4) working in a job that is valued by society, (5) having enough leisure time besides the job, (6) working on interesting tasks on the job, (7) being able to work independently, (8) working on tasks which require a high sense responsibility, (9) having a lot of direct contact with other people, (10) being able to help others through the job, (11) working in a job that is useful to society, (12) having the feeling of contributing something meaningful, and (13) working in a healthy work environment.

We then added the six respect facets as items to be ranked among the other 13 classic work values: (14) working for a supervisor who appreciates my work, (15) working with 
colleagues who appreciate my work, (16) working with colleagues who treat me with respect, (17) working for a supervisor who treats me with respect, (18) working for a supervisor I can respect, (19) working with colleagues I can respect.

In both studies, participants were asked to indicate how important they consider each value in a work setting on a scale from 1 "not important" to 5 "very important". The list of values was randomised for each participant to prevent item context effects as outlined by Podsakoff, MacKenzie, Lee and Podsakoff (2003).

In Study 2, we used the same items to additionally assess perceived work practices in organizations. Here, we asked participants to rate the extent of which each practice can be found in their current organization, from 1 "not at all" to 5 "very much".

Results

Although the samples for both studies were collected independently, the work value rankings are highly congruent $\left(r_{s}=.97, p<.001\right)$. The replication of the (mean) value ranks as such over both studies (Table 1) leaves us confident to interpret the ranks in more depth.

\section{[INSERT TABLE 1 ABOUT HERE]}

Respect facets show comparatively high ranks. Employees' supervisors take a prominent role in the ranking. Not only do both studies show that employees generally care highly about the recognition respect that they receive as persons (rank 2 in Study 1 versus rank 3 in Study 2), but also about the appraisal respect represented in the appreciation of one's work (rank 4 vs. 5). Working for a supervisor one can respect scores in the midfield (rank 8 vs. 7). Having a supervisor one can respect seems overall less important to employees than their supervisors' behaviour towards them. Yet, it still outscores work values such as high income (rank 14 vs. 
15), career opportunities (rank 15 vs. 14), or leisure time aside the duties of the job (rank 19 in both).

When looking at the same respect facets for employees' colleagues, we find that these are ranked in the same order to each other as those for the supervisor only that they score about 4 ranks lower than the corresponding supervisor related facets. Altogether, results show that the supervisor takes a more prominent role in employees' work values than their colleagues do.

Apart from the respect facets, Table 1 also shows that directly task related aspects such as working on an interesting tasks (rank 1 in both), contributing something meaningful (rank 5 vs. 4) or being able to work independently (rank 3 vs. 2) score rather highly compared to other aspects such as career opportunities, income, leisure time aside the job, and status in society.

\section{[INSERT TABLE 2 ABOUT HERE]}

When comparing employees' work value ranking with the organizational work practice ranking in the second study (Table 2$)$, we find that these correspond to a certain extent $\left(r_{s}=.59\right.$, $p<.05)$, indicating that priorities in employees' work values are somewhat matched by perceived organizational work practices when looked upon at an aggregated level. Facets of respect involving colleagues, for example, occupy rather similar ranks in organizational practices and employees' rankings. Yet, apart from the congruence between work values and perceived practices, some divergences constitute the lack of congruence indices in our analyses. We can note, for example, that all aspects which involve employees' supervisors show a negative divergence. This indicates that supervisor related aspects in organizations are generally not prioritized as highly as employees would like.

Additionally, we can observe that most work values and perceptions on analogous practices are correlated on an individual level, too. Compared with the correlations on the 
aggregate level however, we find a lower mean correlation over all values of .30 (calculated via Fishers' Z), indicating that not all employees find their value priorities confirmed in their organizations to the extent they desire them.

Aside from the respect facets, we find that the issue of health in the workplace also diverges negatively from the importance that employees assign to it. Although, it was already not rated very highly in employee value ranks (rank 7 vs. 9), it is evidently prioritized even lower in organizations (rank 16) so that discrepancy results in Table 2 are highest here. Additionally, this value-practice pair is the only one that does not show any significant relationship on an individual level, underlining that individual preferences on this issue are not at all reflected by the organizations these individuals work for. On the other end of the divergences, we can observe that values which employees did not emphasize in their personal value rankings, such as direct contact with other people or working on tasks which require a lot of responsibility, seem to occupy a comparatively high emphasis in their perceptions of organizational practices.

\section{Discussion}

Both studies produced a value ranking that is by and large congruent. The concept that values are relatively stable within a society has been noted before (Rokeach, 1973) and is, although the degree of congruence is very high, by itself not very surprising. It is interesting to note however that the different facets of respect are clearly a priority within employees' personal value rankings. Generally, there is a higher concern about respect issues involving people's supervisor than those involving colleagues. Within the respect facets, recognition respect seems to play the most prominent role. At the same time, the appraisal respect as indicated by appreciation of one's work is also of high, but not as high concern. Out of the three respect facet measurements, the appraisal respect which people can accord to their supervisors or colleagues is 
of least priority. Although it still scores in the midfield of the measured values, it is evident that employees' foremost concern is how they are being treated rather than if they work for or with people whom they can respect.

That respect with regards to supervisors is an issue within organizations is additionally emphasized by the comparison of the work value with the work practices ranking. All three respect facets involving supervisors diverged highly between values and perceived practices, indicating that the behaviour of supervisors towards their subordinates seems to be somewhat of a blind spot within organizational priorities. This is not to say that they do not receive any attention in the organizational development process, but the emphasis probably does not lie on the quality of the relationship supervisors have with their subordinates - at least, in employees' perceptions. Considering previous results on the impact of respect (De Cremer, 2003; Miller, 2001; Simon \& Stürmer, 2003; Tyler \& Blader, 2000), particularly the impact leaders (and their behaviours) have on organizational outcomes (Judge et al., 2004; Yukl, 2002), it seems that this is a potentially worrisome blind spot as performance and employees' satisfaction might be lost here. On the upside, it is encouraging to see how much potential still lies idle and awaits awakening.

Apart from the topic of respect and somewhat unexpected, we find additional high divergences with regard to health issues. Although employees did already not rank health issues particularly high in their importance among other work values, it is rather troublesome to see that organizations seem to prioritize them even to a lesser extent. At this point however, we may only speculate that this is the case because organizations have not yet reacted upon the stressors that mark modern days' work (Robinson \& Clore, 2001; Sparks, Faragher, \& Cooper, 2001). Also, it should be noted here that data were collected in Germany. As previous work would indicate that 
work values and practices considerably differ between countries (Chhokar, Brodbeck, \& House, 2007; Hofstede, 1991; House, Hanges, Javidan, Dorfman, \& Gupta, 2004), the here obtained results should not be generalized.

When looking at the data on an individual level, it is interesting to observe that most values corresponded with the analogous work practice to a certain degree. This may either indicate that people chose a job according to their values (Judge \& Bretz, 1992), or that people's values are somewhat shaped by the practice they encounter every day. Either way, the perceived priorities of an organization can also be found within the individuals working for it. If issues of respect are not emphasized by the organization, it is likely that they either attract or shape employees the same way. Naturally, due to the cross sectional design of the studies, it is important to note that a clear causal point on this issue cannot be made here. A certain degree of the observed correlations might also be due to common source variance (Podsakoff et al., 2003) and thus overestimate the correlations. While issues of causality may be addressed with longitudinal research in this case (i.e., investigate how or if employees' work values change depending upon the practices they find in a company that they start to work for), common source variance could be addressed, for instance, by employing some sort of implicit measurement of work values. This way, one could also account for social desirability effects which potentially confound responses on values (Pryor, 1983). Also, desirability effects due to different selfconceptions (Higgins, 1987, i.e., conflicts between employees' actual, ideal, and ought self) could be explored with such a method and thus offer extended insights on the "facade"- or “impression management”-function of values.

Likewise, employees' ratings on work practices might not always equate to what the organization actually does or tries to do. In this respect, it would be highly valuable to obtain 
data from both sides, employees' ratings of organizational work practices and ratings from those who are in charge of putting work values into practice in that organizations, i.e. human resources departments or management executives. Such data would even render extended hypotheses on the congruence of work practice perceptions between employees and management testable which could potentially reveal if certain issues are really a blind spot to management.

Respect issues, in particular those involving supervisors, are certainly a fascinating topic to shed further light upon. Evidently, as employees often perceive their supervisors to lack respect for them, there is much potential to be used for the benefit of organizations and employees alike. 


\section{References}

Bass, B. M., \& Stogdill, R. M.: 1990, Bass \& Stogdill's handbook of leadership: Theory, research, and managerial applications, 3rd edition (Free Press, New York, London).

Bem, D. J.: 1970, Beliefs, attitudes, and human affairs, (Brooks-Cole, Belmont, CA).

Birnbaum, M. H.: 2004, 'Human research and data collection via the internet', Annual Review of Psychology 55, 803-832.

Branscombe, N. R., Spears, R., Ellemers, N., \& Doosje, B.: 2002, 'Intragroup and intergroup evaluation effects on group behavior', Personality \& Social Psychology Bulletin 28(6), 744-753.

Chhokar, J. S., Brodbeck, F. C., \& House, R. J. (Eds.). (2007). Culture and leadership across the world: The GLOBE book of in-depth studies of 25 societies. Mahwah, NJ: LEA Publishers.

Darwall, S. L.: 1977, 'Two kinds of respect', Ethics 88(1), 36-49.

De Cremer, D.: 2003, 'Noneconomic motives predicting cooperation in public good dilemmas: The effect of received respect on contributions', Social Justice Research 16(4), 367-377.

Dillon, R. S.: 2003, 'Respect', in E. N. Zalta (ed.), The Stanford Encyclopedia of Philosophy, Fall 2003 edition., Vol.

Eckloff, T., \& van Quaquebeke, N.: 2008, 'Entwicklung und Validierung einer Skala zu respektvoller Führung [Development and validiation of a scale on respectful leadership]', in E. H. Witte (ed.), Sozialpsychologie und Werte, (Pabst Science Publishers, Lengerich), pp. 243-275.

Epstein, S.: 1979, 'The stability of behavior: On predicting most of the people much of the time', Journal of Personality and Social Psychology 37(7), 1097-1126. 
Higgins, E. T.: 1987, 'Self-discrepancy: A theory relating self and affect', Psychological Review 94(3), 319-340.

Hill, T. E., Jr.: 1998, 'Respect for persons', in E. Craig (ed.), Routledge Encyclopedia of Philosophy, (Routledge, London).

Hofstede, G. H.: 1991, Cultures and organizations: Software of the mind, (McGraw-Hill, London, New York).

House, R. J., Hanges, P. J., Javidan, M., Dorfman, P., \& Gupta, V.: 2004, Culture, leadership, and organizations: The GLOBE study of 62 societies, (Sage Publications, Thousand Oaks, CA).

Jones, E. E., \& Gerard, H.: 1967, Foundations of social psychology, ((1967). Oxford, England: Wiley. Wiley Print,

Judge, T. A., \& Bretz, R. D.: 1992, 'Effects of work values on job choice decisions', Journal of Applied Psychology 77(3), 261-271.

Judge, T. A., Piccolo, R. F., \& Ilies, R.: 2004, 'The forgotten ones? The validity of consideration and initiating structure in leadership research', Journal of Applied Psychology 89(1), 3651.

Kant, I.: 2003, Kritik der praktischen Vernunft. Kritik der Urtheilskraft, Reprint of the 1968 edition (de Gruyter, Berlin).

Kerr, S., Schreisheim, C. A., Murphy, C. J., \& Stogdill, R. M.: 1974, 'Toward a contingency theory of leadership based upon the consideration and initiating structure literature', Organizational Behavior \& Human Performance 12(1), 62-82. 
Kraut, R., Olson, J., Banaji, M., Bruckman, A., Cohen, J., \& Couper, M.: 2004, 'Psychological research online: Report of board of scientific affairs' advisory group on the conduct of research on the internet', American Psychologist 59(2), 105-117.

Locke, E. A.: 1976, 'The nature and causes of job satisfaction', in M. Dunnett (ed.), The handbook of industrial and organizational psychology, (Rand-McNally, Chicago, IL), pp. 1297-1349.

Mason, E. S.: 1994, 'Work values: A gender comparison and implications for practice', Psychological Reports 74(2), 415-418.

Meglino, B. M., \& Ravlin, E. C.: 1998, 'Individual values in organizations: Concepts, controversies, and research', Journal of Management 24(3), 351-389.

Miller, D. T.: 2001, 'Disrespect and the experience of injustice', Annual Review of Psychology 52, 527-552.

Podsakoff, P. M., MacKenzie, S. B., Lee, J.-Y., \& Podsakoff, N. P.: 2003, 'Common method biases in behavioral research: A critical review of the literature and recommended remedies', Journal of Applied Psychology 88(5), 879-903.

Pryor, R. G.: 1983, 'The influence of social desirability as a response set on the measurement of values/preferences related to work', Australian Psychologist 18(3), 359-369.

Robinson, M. D., \& Clore, G. L.: 2001, 'Simulation, scenarios, and emotional appraisal: Testing the convergence of real and imagined reactions to emotional stimuli', Personality and Social Psychology Bulletin 27(11), 1520-1532.

Rokeach, M.: 1973, The nature of human values, (Free Press, New York).

Simon, B.: 2007, 'Respect, equality, and power: A social psychological perspective', Gruppendynamik und Organisationsberatung 38(3), 309-326. 
Simon, B., \& Stürmer, S.: 2003, 'Respect for group members: Intragroup determinants of collective identification and group-serving behavior', Personality \& Social Psychology Bulletin 29(2), 183-193.

Simon, B., \& Stürmer, S.: 2005, 'In search of the active ingredient of respect: A closer look at the role of acceptance', European Journal of Social Psychology 35(6), 809-818.

Sleebos, E., Ellemers, N., \& de Gilder, D.: 2006, 'The carrot and the stick: Affective commitment and acceptance anxiety as motives for discretionary group efforts by respected and disrespected group members', Personality and Social Psychology Bulletin 32(2), 244-255.

Smith, H. J., Tyler, T. R., Huo, Y. J., Ortiz, D. J., \& Lind, E. A.: 1998, 'The self-relevant implications of the group-value model: Group membership, self-worth, and treatment quality', Journal of Experimental Social Psychology 34(5), 470-493.

Sparks, K., Faragher, B., \& Cooper, C. L.: 2001, 'Well-being and occupational health in the 21st century workplace', Journal of Occupational and Organizational Psychology 74(4), 489509.

Spears, R., Ellemers, N., \& Doosje, B.: 2005, 'Let me count the ways in which I respect thee: Does competence compensate or compromise lack of liking from the group?' European Journal of Social Psychology 35(2), 263-279.

Stogdill, R. M.: 1950, 'Leadership, membership and organization', Psychological Bulletin 47(1), $1-14$.

Tyler, T. R., \& Blader, S. L.: 2000, Cooperation in groups: Procedural justice, social identity, and behavioral engagement, (Psychology Press, Philadelphia). 
Tyler, T. R., \& Blader, S. L.: 2003, 'The group engagement model: Procedural justice, social identity, and cooperative behavior', Personality \& Social Psychology Review 7(4), 349361.

van Quaquebeke, N., Henrich, D. C., \& Eckloff, T.: 2007, '“It's not tolerance I'm asking for, it's respect!" A conceptual framework to differentiate between tolerance, acceptance and respect', Gruppendynamik und Organisationsberatung 38(2), 185-200.

Vroom, V. H.: 1964, Work and motivation, (Wiley, Oxford).

Williams, R. M., Jr.: 1979, 'Change and stability in values and value systems: A sociological perspective', in M. Rokeach (ed.), Understanding human values, (Free Press, New York), pp. 15-46.

Yukl, G. A.: 2002, Leadership in organizations, 5th edition (Prentice Hall, Upper Saddle River, $\mathrm{NJ}$ ). 


\section{Endnotes}

${ }^{1}$ The recognition respect that employees may or may not show towards their supervisors and colleagues cannot be integrated because, as stated above, it is a categorical issue and can not be answered with more or less important, e.g., one cannot say that being able to have colleagues one can respect as people is a desirable work value. One either respects people as humans, or one does not. 
Table 1: Descriptive statistics for work values in Study 1 and 2

\begin{tabular}{|c|c|c|c|c|c|c|c|}
\hline \multirow[b]{2}{*}{ Work values } & \multicolumn{3}{|c|}{ Study 1} & \multicolumn{3}{|c|}{ Study 2} & \multirow{2}{*}{$\begin{array}{l}\text { Rank } \\
\text { difference }\end{array}$} \\
\hline & $M$ & $S D$ & Rank & $M$ & $S D$ & Rank & \\
\hline Working on interesting tasks on the job & 4.50 & 0.64 & 1 & 4.63 & 0.52 & 1 & 0 \\
\hline Working for a supervisor who treats me with respect & 4.41 & 0.71 & 2 & 4.34 & 0.69 & 3 & 1 \\
\hline Being able to work independently & 4.38 & 0.73 & 3 & 4.41 & 0.64 & 2 & 1 \\
\hline Working for a supervisor who appreciates my work & 4.30 & 0.75 & 4 & 4.31 & 0.69 & 5 & 1 \\
\hline Having the feeling of contributing something meaningful & 4.26 & 0.76 & 5 & 4.33 & 0.76 & 4 & 1 \\
\hline Working with colleagues who treat me with respect & 4.23 & 0.70 & 6 & 4.27 & 0.65 & 6 & 0 \\
\hline Working in a healthy work environment & 4.11 & 0.83 & 7 & 4.13 & 0.76 & 9 & 2 \\
\hline Working for a supervisor I can respect & 3.94 & 0.94 & 8 & 4.26 & 0.72 & 7 & 1 \\
\hline Working on tasks which require a high sense of responsibility & 3.90 & 0.82 & 9 & 4.10 & 0.76 & 10 & 1 \\
\hline Working with colleagues who appreciate my work & 3.89 & 0.81 & 10 & 4.04 & 0.65 & 11 & 1 \\
\hline Having high job security & 3.82 & 0.97 & 11 & 3.95 & 0.85 & 12 & 1 \\
\hline Working with colleagues I can respect & 3.77 & 0.84 & 12 & 4.15 & 0.63 & 8 & 4 \\
\hline Having a lot of direct contact with other people & 3.61 & 0.97 & 13 & 3.81 & 0.90 & 13 & 0 \\
\hline Receiving a high income & 3.46 & 0.83 & 14 & 3.67 & 0.76 & 15 & 1 \\
\hline Having good career opportunities & 3.45 & 0.86 & 15 & 3.77 & 0.87 & 14 & 1 \\
\hline Working in a job that is useful to society & 3.28 & 0.98 & 16 & 3.49 & 0.96 & 16 & 0 \\
\hline Working in a job that is accepted and valued by society & 3.17 & 0.97 & 17 & 3.31 & 0.93 & 18 & 1 \\
\hline Being able to help others through my job & 3.15 & 1.00 & 18 & 3.41 & 0.96 & 17 & 1 \\
\hline Having enough leisure time aside the job & 3.12 & 0.96 & 19 & 3.29 & 0.91 & 19 & 0 \\
\hline
\end{tabular}

Note. $N_{1}=589, N_{2}=318$; all indications were made on a Likert scale ranging from 1 (not important) to 5 (very important). 
Table 2: Descriptive statistics for work practices and correlations with the corresponding work values in Study 2 sorted by rank differences

\begin{tabular}{|c|c|c|c|c|c|}
\hline Work practice & $M$ & $S D$ & Rank & $\begin{array}{l}\text { Difference in ranks } \\
\text { between work value } \\
\text { and work practice in } \\
\text { Study } 2\end{array}$ & $\begin{array}{l}\text { Correlation with } \\
\text { corresponding work } \\
\text { value }\end{array}$ \\
\hline Working in a healthy work environment & 3.30 & 1.06 & 16 & -7 & .06 \\
\hline Working for a supervisor who appreciates my work & 3.62 & 1.16 & 11 & -6 & $.28 * * *$ \\
\hline Working for a supervisor who treats me with respect & 3.77 & 1.14 & 8 & -5 & $.25 * * *$ \\
\hline Working for a supervisor I can respect & 3.57 & 1.19 & 12 & -5 & $.26^{* * *}$ \\
\hline Having good career opportunities & 2.62 & 1.14 & 18 & -4 & $.30 * * *$ \\
\hline Having the feeling of contributing something meaningful & 3.78 & 1.02 & 7 & -3 & $.21 * * *$ \\
\hline Having high job security & 3.35 & 1.29 & 15 & -3 & $.28 * * *$ \\
\hline Working on interesting tasks on the job & 4.12 & 0.90 & 3 & -2 & $.20 * *$ \\
\hline Being able to work independently & 4.10 & 0.88 & 4 & -2 & $.50 * * *$ \\
\hline Receiving a high income & 2.78 & 1.08 & 17 & -2 & $.29 * * *$ \\
\hline Having enough leisure time aside the job & 2.48 & 1.13 & 19 & 0 & $.27 * * *$ \\
\hline Working with colleagues who treat me with respect & 4.06 & 0.77 & 5 & 1 & $.26^{* * *}$ \\
\hline Working with colleagues who appreciate my work & 3.77 & 0.78 & 9 & 2 & $.22 * * *$ \\
\hline Working with colleagues I can respect & 4.01 & 0.75 & 6 & 2 & $.25 * * *$ \\
\hline Being able to help others through my job & 3.42 & 1.27 & 14 & 3 & $.52 * * *$ \\
\hline Working in a job that is accepted and valued by society & 3.53 & 1.02 & 13 & 5 & $.15^{*}$ \\
\hline Working in a job that is useful to society & 3.66 & 1.14 & 10 & 6 & $.41 * * *$ \\
\hline Working on tasks which require a high sense of responsibility & 4.18 & 0.91 & 2 & 8 & $.36^{* * *}$ \\
\hline Having a lot of direct contact with other people & 4.24 & 0.91 & 1 & 12 & $.46^{* * *}$ \\
\hline
\end{tabular}

Note. $N_{2}=318 ; * p<.05 ; * *<.01 ; * * * p<.001$; all indications were made on a Likert scale ranging from 1 (not at all / not important) to 5 (very much / very important). 


\section{Publications in the ERIM Report Series Research* in Management}

\section{ERIM Research Program: "Organizing for Performance"}

2008

Explaining Preferences and Actual Involvement in Self-Employment: New Insights into the Role of Gender Ingrid Verheul, Roy Thurik and Isabel Grilo ERS-2008-003-ORG

http://hdl.handle.net/1765/10979

Public Finance in China since the Late Qing Dynasty

Barbara Krug

ERS-2008-005-ORG

http://hdl.handle.net/1765/11287

Overoptimism among Founders: The Role of Information and Motivation

Ingrid Verheul and Martin Carree

ERS-2008-008-ORG

http://hdl.handle.net/1765/11557

Do Foreign Greenfields Outperform Foreign Acquisitions or Vice Versa? An Institutional Perspective

Arjen H.L. Slangen and Jean-François Hennart

ERS-2008-009-ORG

http://hdl.handle.net/1765/11558

Unemployment Benefits Crowd Out Nascent Entrepreneurial Activity

Philipp Koellinger and Maria Minniti

ERS-2008-012-ORG

http://hdl.handle.net/1765/11808

Acceleration of Technology Adoption within Firms: Empirical Evidence from the Diffusion of E-business Technologies Philipp Koellinger and Christian Schade

ERS-2008-013-ORG

http://hdl.handle.net/1765/11809

Belbin Revisited: The Construct Validity of the Interplace II Team Role Instrument

Dirk van Dierendonck and Rob Groen

ERS-2008-017-ORG

http://hdl.handle.net/1765/12123

China's Institutional Architecture: A New Institutional Economics and Organization Theory Perspective on the Links between Local Governance and Local Enterprises

Barbara Krug and Hans Hendrischke

ERS-2008-018-ORG

http://hdl.handle.net/1765/12191

Ethics Programs and Ethical Cultures: A Next Step in Unraveling their Multi-Faceted Relationship

Muel Kaptein

ERS-2008-020-ORG

http://hdl.handle.net/1765/12192

Entrepreneurship Education and Training in a Small Business Context: Insights from the Competence-based Approach Thomas Lans, Wim Hulsink, Herman Baert and Martin Mulder

ERS-2008-028-ORG

http://hdl.handle.net/1765/12466

The Relationship between Technology, Innovation, and Firm Performance: Empirical Evidence on E-Business in Europe

Philipp Koellinger

ERS-2008-031-ORG

http://hdl.handle.net/1765/12469 
The Relationship between Ethical Culture and Unethical Behavior in Work Groups: Testing the Corporate Ethical Virtues Model

Muel Kaptein

ERS-2008-037-ORG

http://hdl.handle.net/1765/12783

Influence Costs in Agribusiness Cooperatives: Evidence from Case Studies

Constantine lliopoulos and George Hendrikse

ERS-2008-040-ORG

http://hdl.handle.net/1765/12872

The Locus of Innovation in Small and Medium-sized Firms: The Importance of Social Capital and Networking in Innovative Entrepreneurship

Willem Hulsink, Tom Elfring and Wouter Stam

ERS-2008-041-ORG

http://hdl.handle.net/1765/12873

Stimulating Strategically Aligned Behaviour among Employees

Cees B. M. van Riel, Guido Berens and Majorie Dijkstra

ERS-2008-045-ORG

http://hdl.handle.net/1765/12903

Science and Technology-based Regional Entrepreneurship in the Netherlands: Building Support Structures for Business

Creation and Growth Entrepreneurship

Willem Hulsink, Kashifa Suddle and Jolanda Hessels

ERS-2008-048-ORG

http://hdl.handle.net/1765/13220

I Can't Get No Satisfaction - Necessity Entrepreneurship and Procedural Utility

Joern Block and Philipp Koellinger

ERS-2008-051-ORG

http://hdl.handle.net/1765/13221

Financial Geographies and Emerging Markets in Europe

Bas Karreman

ERS-2008-054-ORG

http://hdl.handle.net/1765/13222

Entrepreneurship, Economic Growth and Policy in Emerging Economies

Roy Thurik

ERS-2008-060-ORG

http://hdl.handle.net/1765/13318

License to Fail? How Leader Group Prototypicality Moderates the Effects of Leader Performance on Perceptions of Leadership Effectiveness

Steffen R. Giessner, Daan van Knippenberg, and Ed Sleebos

ERS-2008-066-ORG

http://hdl.handle.net/1765/13626

The Effect of Legal Families on the Development of Business Law in China: Who's Really Writing the Rules of the Game? Barbara Krug and Nathan Betancourt

ERS-2008-068-ORG

http://hdl.handle.net/1765/13764

Market Feedback and Team Commitment in Radical Product Innovation Process

Luca Berchicci and Christopher Tucci

ERS-2008-069-ORG

http://hdl.handle.net/1765/13765 
The Strategic Determinants of Tardy Entry: Is Timeliness Next to Godliness?

Luca Berchicci, Andrew King, and Christopher Tucci

ERS-2008-070-ORG

http://hdl.handle.net/1765/13766

Businessman or Host? Individual Differences between Entrepreneurs and Small Business Owners in the Hospitality Industry Stephanie L. Wagener, Marjan J. Gorgievski, and Serge A. Rijsdijk

ERS-2008-073-ORG

http://hdl.handle.net/1765/13832

Understanding a Two-Sided Coin: Antecedents and Consequences of a Decomposed Product Advantage

Serge A. Rijsdijk, Fred Langerak, and Erik Jan Hultink

ERS-2008-074-ORG

http://hdl.handle.net/1765/13833

A Treatise on the Geographical Scale of Agglomeration Externalities and the Modifiable Areal Unit Problem Martijn J. Burger, Frank G. van Oort, and Bert van der Knaap

ERS-2008-076-ORG

http://hdl.handle.net/1765/13834

That which Doesn't Break Us: Identity Work in the Face of Unwanted Development

Gail Whiteman and Eveline Bruijn

ERS-2008-078-ORG

http://hdl.handle.net/1765/13877

Projected Destination Images on African Websites: Upgrading Branding Opportunities in the Global Tourism Value Chain Jeroen van Wijk, Frank M. Go, and Robert Govers

ERS-2008-079-ORG

http://hdl.handle.net/1765/14002

Making Retail Supply Chains Sustainable: Upgrading Opportunities for Developing Country Suppliers under Voluntary Quality Standards

Jeroen van Wijk, Myrtille Danse, and Rob van Tulder

ERS-2008-080-ORG

http://hdl.handle.net/1765/14003

Find out how Much it Means to Me! The Importance of Interpersonal Respect in Work Values Compared to Perceived Organizational Practices

Niels van Quaquebeke, Sebastian Zenker, and Tilman Eckloff

ERS-2008-085-ORG

http://hdl.handle.net/1765/14311

* A complete overview of the ERIM Report Series Research in Management:

https://ep.eur.nl/handle/1765/1

ERIM Research Programs:

LIS Business Processes, Logistics and Information Systems

ORG Organizing for Performance

MKT Marketing

F\&A Finance and Accounting

STR Strategy and Entrepreneurship 